\title{
Commentary: Immunology's Coming of Age
}

\author{
Heinz Kohler ${ }^{1 *}$, Anastas Dimitrov Pashov ${ }^{2}$ and Thomas Kieber-Emmons ${ }^{3}$ \\ ${ }^{1}$ Department of Microbiology and Immunology, University of Kentucky, Lexington, KY, United States, ${ }^{2}$ Stephan Angelov \\ Institute of Microbiology, Bulgarian Academy of Sciences, Sofia, Bulgaria, ${ }^{3}$ Pathology, University of Arkansas for Medical \\ Sciences, Little Rock, AR, United States
}

Keywords: antibody, idiotype, selection, natural antibody, therapeutic antibody

\author{
A Commentary on \\ Immunology's Coming of Age \\ by Kaufmann, S. H. E. (2019). Front. Immunol. 10:684. doi: 10.3389/fimmu.2019.00684
}

\section{OPEN ACCESS}

Edited by:

Alessandra Mortellaro,

San Raffaele Telethon Institute for Gene Therapy (SR-Tiget), Italy

Reviewed by:

Luuk Hilbrands,

Radboud University Nijmegen,

Netherlands

*Correspondence: Heinz Kohler

heinz.kohler@uky.edu

Specialty section:

This article was submitted to

Molecular Innate Immunity,

a section of the journal

Frontiers in Immunology

Received: 26 June 2019

Accepted: 28 August 2019

Published: 12 September 2019

Citation:

Kohler $\mathrm{H}$, Pashov $A D$ and

Kieber-Emmons T (2019)

Commentary: Immunology's Coming of Age. Front. Immunol. 10:2175. doi: 10.3389/fimmu.2019.02175
The recent review by Stefan Kaufmann on "Immunology's Coming of Age" is an elegant historical outline of the evolution of Immunology with focusing on a particular perspective of the history of Immunology, that is Nobel Laureate contributions to the discipline. Immunology is a difficult discipline to survey. Even the best attempts would ultimately focus on some selected aspects. As such, it invites comments aiming to complement the presented history in the context of Immunology coming of age. It is the aim of our Commentary to add important research in the field of immunology to demonstrate that it has become a self-containing discipline.

\section{INTRODUCTION}

Immunology is a rich discipline with successes and failures, with various scholarly works describing its origins and history that lend to our current understanding of immunological principles $(1,2)$. Still another perspective has been presented recently by Stefan Kaufmann emphasizing notable contributions acknowledged by the awarding of a Nobel Prize to outstanding investigators (3). While touching on extremely important developments, important contextual elements need to be mentioned to complement the presented history as important contributions are not always recognized by a Nobel Prize.

\section{DISCUSSION}

\section{Antibody Recognition and Diversity}

Saying that Immunology is an interdisciplinary science may no longer be entirely true since now it has also its own methods. The most prominent immunological paradigm is the concept of antibody. The specificity of antibodies is still an important question in immunology. Historically, the generation of diversity of antibodies was a hot discussed topic in the middle of the twentieth century initiated by the template hypothesis of Breinl and Haurowitz in 1930 (4), 10 years prior to Pauling's claim, cited in Kaufmann's review, that antibodies were made by folding newly synthesized nascent antibody polypeptide chains around the antigens, which serve as a template. Breinl and Haurowitz "thought that antibodies acquired their specificity for antigen by folding of the newly synthesized nascent polypeptide chain around the antigen" (5). The biochemical properties of antigen-antibody binding interactions were examined in more detail in the late 1930s by John Marrack (6). The biomolecule responsible for these actions was termed antitoxin, precipitin, and agglutinin. It was not known that all three substances were one entity. This was later demonstrated by Elvin A. Kabat showing the heterogeneity of antibodies through ultracentrifugation studies of 
horses' sera. Similarly, an equally important milestone in the understanding of Immunological recognition was the $\mathrm{x}$-ray resolution of a Fab antibody fragment (7) not recognized in the review and the founding of the definition of antibody diversity and its biological significance by $\operatorname{Kabat}(8,9)$. This work provided a transforming view of antibody diversity and the molecular basis for antigen recognition (10).

\section{Idiotype Hypothesis}

Niels Jerne made several important contributions to Immunology. Niels Jerne's antibody selection theory is cited, but his more important contribution in the field of Immunobiology, the Idiotypic Network hypotheses, is not mentioned being essential for a historical record (11). He suggested that antibodies could be recognized as foreign, inducing other antibodies and thereby forming a network. Neglecting idiotype may be seen as more of a cultural aspect since it has not been accepted as a mainstream theory. Nevertheless, it has left a considerable imprint in immunological thinking. Recent reviews in Frontiers address the importance of the Idiotype concept in Immunology $(12,13)$. It might be argued that the Idiotypic Network hypothesis is the forerunner of present day ideas on the role antibodies plays in integrative Systems Immunology (14).

\section{Selection}

Positive and negative selection (of both $\mathrm{T}$ and $\mathrm{B}$ cells) as well as the practical and theoretical aspects of intravenous immunoglobulins are important Immunology discoveries. The term "tolerance" was first coined by Ray Owen in reference to a physiological state he observed in dizygotic twin cattle (15) as noted in a review of the historical record of immunological tolerance (16). Just like antibodies, the elucidation of the $\mathrm{T}$ cell structure was monumental $(17,18)$. This facet provided the backdrop of monumental studies by Ellis Reinherz, Phillippa Marrack, John Kappler, and James Allison. Checkpoint inhibitors, which are driving Immmunotherapy,

\section{REFERENCES}

1. Silverstein AM. History of Immunology. eLS (2001). doi: 10.1038/npg.els.0003078

2. Smith KA. Editorial: a living history of immunology. Front Immunol. (2015) 6:502. doi: 10.3389/fimmu.2015.00502

3. Kaufmann SHE. Immunology's coming of age. Front Immunol. (2019) 10:684. doi: 10.3389/fimmu.2019.00684

4. Breinl F, Haurowitz F. Chemische Untersuchung des Prazipitates aus Hamoglobin und Anti-Hamoglobin-Serum und Bemerkungen uber die Natur der Antikorper. F Hoppe-Seyler Z. Physiol Chem. (1930) 192:45. doi: 10.1515/bchm2.1930.192.1-3.45

5. Eisen HN, Schlesinger S. Remembrance of immunology past: conversations with Herman Eisen. Annu Rev Immunol. (2015) 33:1-28. doi: 10.1146/annurev-immunol-111214-122349

6. Marrack J. Nature of antibodies. Nature. (1934) 133:292-3. doi: 10.1038/133292b0

7. Rudikoff S, Potter M, Segal DM, Padlan EA, Davies DR. Crystals of phosphorylcholine-binding Fab-fragments from mouse myeloma proteins: preparation and x-ray analysis. Proc Natl Acad Sci USA. (1972) 69:3689-92. doi: 10.1073/pnas.69.12.3689 owe their existence to the understanding of how $\mathrm{T}$ cells in particular function.

\section{Natural Antibodies}

Of no less importance is the regulatory and therapeutic potential of natural antibodies (19). Natural antibodies play an important role in the first line of defense and house keeping $(20,21)$. For a long period, natural antibodies were merely regarded as insignificant background of immunity. However, an early study in 1925 indicated that natural antibody in normal serum could neutralize bacteria (22).

\section{Therapeutic Antibodies}

With the discovery of immortalizing antibodies by Kohler and Milstein (23) opened a new drug class to treat infections, auto-immunities and other diseases $(24,25)$. In parallel intravenous immunoglobulin (IVIg) emerged as standard therapy of immunoglobulin deviancies, auto-immune reactions and in homeostasis (26-28). These translationary aspects of Immunology deserve to be noticed.

\section{CONCLUSION}

The History of Immunology began with Edward Jenner's discovery that vaccination protects against smallpox. Many scientists and discoveries have since lent to our understanding of how the immune system fights disease and sometimes causes disease as well to new classes of drugs. As we move closer to individualized medicine scenarios there will be a continuing need to understand and maybe redefine what came before and what will evolve in the discipline Immunology.

\section{AUTHOR CONTRIBUTIONS}

All authors listed have made a substantial, direct and intellectual contribution to the work, and approved it for publication.

8. Kabat EA. Heterogeneity and structure of antibody-combining sites. Ann N Y Acad Sci. (1970) 169:43-54. doi: 10.1111/j.1749-6632.1970.tb55968.x

9. Wu TT, Kabat EA. An analysis of the sequences of the variable regions of Bence Jones proteins and myeloma light chains and their implications for antibody complementarity. J Exp Med. (1970) 132:211-50. doi: $10.1084 /$ jem.132.2.211

10. Hood LE. Wu and Kabat 1970: a transforming view of antibody diversity. $J$ Immunol. (2008) 180:7055-6. doi: 10.4049/jimmunol.180.11.7055

11. Jerne NK. Towards a network theory of the immune system. Ann Immunol. (1974) 125C:373-89.

12. Kieber-Emmons T, Monzavi-Karbassi B, Pashov A, Saha S, Murali R, Kohler H. The promise of the anti-idiotype concept. Front Oncol. (2012) 2. doi: $10.3389 /$ fonc. 2012.00196

13. Lemke $H$. Antigen receptor-intrinsic non-self: the key to understanding regulatory lymphocyte-mediated idiotypic control of adaptive immune responses. Crit Rev Immunol. (2016) 36:13-56. doi: 10.1615/CritRevImmunol.2016016606

14. Li S, Rouphael N, Duraisingham S, Romero-Steiner S, Presnell S, Davis C, et al. Molecular signatures of antibody responses derived from a systems biology study of five human vaccines. Nat Immunol. (2014) 15:195-204. doi: 10.1038/ni.2789 
15. Owen RD. Immunogenetic consequences of vascular anastomoses between bovine twins. Science. (1945) 102:400-1. doi: 10.1126/science.102.2651.400

16. Schwartz RH. Historical overview of immunological tolerance. Cold Spring Harb Perspect Biol. (2012) 4:a006908. doi: 10.1101/cshperspect.a00 6908

17. Yanagi Y, Yoshikai Y, Leggett K, Clark SP, Aleksander I, Mak TW. A human $\mathrm{T}$ cell-specific cDNA clone encodes a protein having extensive homology to immunoglobulin chains. Nature. (1984) 308:145-9. doi: 10.1038/308 $145 \mathrm{a} 0$

18. Hedrick SM, Cohen DI, Nielsen EA, Davis MM. Isolation of cDNA clones encoding T cell-specific membrane-associated proteins. Nature. (1984) 308:149-53. doi: 10.1038/308149a0

19. Briles DE, Nahm M, Schroer K, Davie J, Baker P, Kearney J, Barletta R. Antiphosphocholine antibodies found in normal mouse serum are protective against intravenous infection with type 3 streptococcus pneumoniae. $J$ Exp Med. (1981) 153:694-705. doi: 10.1084/jem.153.3.694

20. Silverman GJ. Protective natural autoantibodies to apoptotic cells: evidence of convergent selection of recurrent innate-like clones. Ann N Y Acad Sci. (2015) 1362:164-75. doi: 10.1111/nyas. 12788

21. Maddur MS, Lacroix-Desmazes S, Dimitrov JD, Kazatchkine MD, Bayry J, Kaveri SV. Natural antibodies: from first-line defense against pathogens to perpetual immune homeostasis. Clin Rev Allergy Immunol. (2019) 2019:87469. doi: 10.1007/s12016-019-08746-9

22. Mackie TJ. Non-specific stimulation of a natural antibody. J Hyg (Lond). (1925) 24:176-88. doi: 10.1017/S0022172400008676

23. Kohler G, Milstein C. Continuous cultures of fused cells secreting antibody of predefined specificity. Nature. (1975) 256:495-7. doi: 10.1038/256495a0
24. Steplewski Z, Thurin M, Kieber-Emmons T. Antibodies: at the nexus of antigens and cancer vaccines. J Infect Dis. (2015) 212:S59-66. doi: 10.1093/infdis/jiu638

25. Shepard HM, Phillips GL, Feldmann M. Developments in therapy with monoclonal antibodies and related proteins. Clin Med (Lond). (2017) 17:220 32. doi: 10.7861/clinmedicine.17-3-220

26. Kaveri SV, Lacroix-Desmazes S, Mouthon L, Kazatchkine MD. Human natural autoantibodies: lessons from physiology and prospects for therapy. Immunologist (1998) 6:227-33.

27. Kazatchkine MD, Kaveri SV. Immunomodulation of autoimmune and inflammatory diseases with intravenous immune globulin. $N$ Engl J Med. (2001) 345:747-55. doi: 10.1056/NEJMra993360

28. Vas J, Grönwall C, Silverman G. Fundamental roles of the innate-like repertoire of natural antibodies in immune homeostasis. Front Immunol. (2013) 4:4. doi: 10.3389/fimmu.2013.00004

Conflict of Interest Statement: The authors declare that the research was conducted in the absence of any commercial or financial relationships that could be construed as a potential conflict of interest.

Copyright (C) 2019 Kohler, Pashov and Kieber-Emmons. This is an open-access article distributed under the terms of the Creative Commons Attribution License (CC BY). The use, distribution or reproduction in other forums is permitted, provided the original author(s) and the copyright owner(s) are credited and that the original publication in this journal is cited, in accordance with accepted academic practice. No use, distribution or reproduction is permitted which does not comply with these terms. 